\title{
Vasylchyshyn 0. \\ INVESTIGATION OF THE EXTERNAL EXPERIENCE OF ANTI-CRISIS POLICY ON THE CONTROL OF FINANCIAL SECURITY OF THE BANKING SYSTEM
}

Об’єктом дослідження є процеси формування антикризової політики розвинутих країн світу та України в контексті реалізації заходів щодо підвищення рівня фінансової безпеки банківської системи. Одним з найбільш проблемних місць в даному дослідженні є те, що досвід зарубіжних країн при імплементуванні його не завжди буде дієвий для України. Це залежить від специфіки економіки, політики, ментальності кожної нащії тощо. Тому, при дослідженні даного об’єкту, а особливу в частині імплементацї та розробки векторів антикризової політики України використовувались методи загальнонаукового пізнання, емпіричного і порівняльного аналізу, синтезу та узагальнення, концептуальних основ забезпечення. Для вирішення проблемних місць враховувалась спещифіка держав щодо забезпечення високого рівня фінансової безпеки вітчизняної банківської системи. Також у дослідженні враховувались складні військово-політичні та економічні реаліі, а також необхідність перегляду основних підходів до управління фінансовою безпекою банківської системи. Одними із головних орієнтирів побудови антикризової політики і концепцї̈ управління фінансовою безпекою банківської системи служив досвід антикризової політики розвинутих країн світу часів Великої Депресії та світової фінансово-економічної кризи 2008-2009 років.

На основі проведеного дослідження сформульовано основні вектори антикризової політики, а саме:

- законодавчий (спрямований на зниження загроз функціонування іноземних державних банків для фінансової безпеки банківської системи Украйни);

- інфраструктурний (спрямований на створення нових елементів банківської інфраструктури, таких як банк «токсичних» активів, банки розвитку, які дозволять підвищити фінансову стійкість всіх банків країни);

- монетарний (направлений на оптимізацію монетарної політики з точки зору забезпечення фінансової, цінової та валютної стабільності);

- фіскальний (зорієнтований на створення позитивного бізнес-середовища і мінімізацій макроекономічних загроз для фінансової безпеки банківської системи). Це пов'язано з тим, що запропоновані вектори становлять гармонійне та дієве поєднання вирішення питання виходу з кризи та забезпечення фінансової безпеки банківської системи в Україні.

Ключові слова: банківська система, фінансова безпека банківської системи, антикризова політика, фіскальна політика, монетарна політика.

\section{Introduction}

Permanent crisis phenomena in the Ukrainian economy and the banking system are caused by structural, legal, managerial imbalances, as well as external shocks, requiring a change in approaches to anti-crisis policies both at the macroeconomic and microeconomic levels. First of all, it concerns anti-crisis measures in the sphere of banking. After all, the banking system, by virtue of its specifics, is one of the key branches of the economy, due to the transformation of the terms of financial assets, redistribution of cash flows in the country. At the same time, it performs an investment function - it stimulates the development of production and is the foundation of economic growth. From these positions, in the context of crisis phenomena in the economy, the issue of ensuring the financial security of the banking system, which is the basis of the financial and economic security of the state as a whole, is very topical.

Vectors of changes in the anti-crisis policy of Ukraine should be based on the experience of the leading coun- tries of the world. These countries by way of a complex combination of management decisions and contrary to the recommendations of modern economic theories and international financial institutions have managed to overcome the world's crises: the Great Depression of 1929-1933 and the financial and economic crisis of 2008-2009. They were based on the historical experience of macroeconomic policy. Moreover, Ukraine's anti-crisis policy should take into account national interests, be comprehensive, aimed at reducing the threats to financial security of the banking system of the internal and external environment, optimizing legislation, infrastructure, coherence of monetary and fiscal policies.

\section{The object of research and its technological audit}

The object of research are the processes of formation of the anti-crisis policy of the developed countries of the world and Ukraine in the context of implementing measures to improve the level of financial security of 
the banking system. After all, the financial security of the banking system directly depends on the effectiveness of the anti-crisis policy, it requires the search for ways to optimize it in Ukraine taking into account the world experience in this field

One of the most problematic places in this research is that the experience of foreign countries will not always be effective for Ukraine depending on the specifics of the economy, politics, the mentality of the nation and the like. Therefore, when studying this object, and especially regarding the implementation and development of vectors of Ukraine's anti-crisis policy, it is necessary to take into account the specifics of states to ensure a high level of financial security of the domestic banking system.

\section{The aim and objectives of research}

The aim of research is research and development of methodological recommendations on the formation of the mechanism of anti-crisis policy and raising the level of financial security of the banking system of Ukraine.

To achieve this aim, it is necessary to perform the following tasks:

1. To study the experience of the formation of the anti-crisis policy mechanism of the President of the United States of America, Franklin Delano Roosevelt, as an effective example.

2. To analyze the vectors of the anti-crisis policy of the United States of America, the European Union and Great Britain during the global financial and economic crisis of 2008-2009.

3. To compare the anti-crisis policy of Ukraine in 2008-2009 with the vectors of the anti-crisis policy of the United States of America, the European Union and Great Britain during the global financial and economic crisis of 2008-2009.

4. To designate vectors for overcoming crisis phenomena in Ukraine, implementing the experience of analyzed foreign countries to ensure a high level of financial security of the domestic banking system.

\section{Research of existing solutions of the problem}

World economic thought has for centuries developed a large number of recommendations on overcoming crisis phenomena and the formation of effective anti-crisis policies that can be combined into the three most pronounced areas of macroeconomic indicators (interest rate, unemployment rate, GDP, money supply):

1) Keynesianism (1936) [1];

2) monetarism (1968) [2];

3) institutionalism (1990) [3].

However, less attention was paid to ensuring the financial security of banking systems, which, as a rule, were the environment for the emergence of crisis phenomena.

Under the influence of the global financial and economic crisis of 2008-2009, in the scientific literature, studies have appeared on overcoming crisis phenomena in the banking system [4-6]. A new wave of developments and recommendations on Ukraine's anti-crisis policy, in particular in the banking sector, was published in 2014-2017, including by foreign economists. Most foreign scientific experts at that time made their recommendations on improving the effectiveness of anti-crisis policies in Ukraine, the introduction of new monetary policy strategies and developing ways to improve the level of financial security of the banking system. However, this was objectively on the whole without an awareness of the essence of the Ukrainian economy and the philosophy of the Ukrainian national life. And also without taking into account national interests and all political, economic, legal imbalances that affect the main trends in the development of the banking system and the state as a whole. For example, when studying the experience of inflation targeting and lessons for Ukraine [7], the author completely omitted the study of the structure of the economies of those countries that introduced inflation targeting. And this significantly distorts the conclusions, because the structure of foreign trade turnover depends on the stability of the national monetary unit, and on the domestic market - the fullness of the state budget and non-monetary inflation factors. This makes it impossible to use inflation targeting as an anti-crisis measure in Ukraine. The same concerns the study of inflationary research in Ukraine [8]. The works of many scientists are devoted to the problems of the monetary and fiscal component of the anti-crisis policy, as well as foreign experience in their implementation, problems of ensuring the financial security of the banking system [9-11]. However, most of those recommendations focus on strategic aspects of governance and development, neglecting the analysis of the real causes of the crisis and the lack of proposals on the complexity of the anti-crisis policy, built on a symbiosis of international experience and Ukrainian realities.

Thus, the results of the analysis allow to conclude that the anti-crisis policy that will ensure the financial security of the banking system for Ukraine, should take into account the specifics of the Ukrainian mentality, politics, economy, banking system, monetary and fiscal policy, and the like.

\section{Methods of research}

The research is based on an empirical and comparative analysis of the practice of the anti-crisis policy of the United States of America (USA) under the rule of President F. Roosevelt. And also the anti-crisis policy of the United States, the European Union and Great Britain in the context of overcoming the consequences of the financial and economic crisis of 2008-2009, as well as ensuring a high level of financial security of banking systems. On the basis of the analysis, practical aspects of the anti-crisis policy of the developed countries of the world and measures to solve the problems of financial security of banking systems have been synthesized. The method of generalization formed methodical recommendations on the construction of the mechanism of anti-crisis policy in Ukraine and a comprehensive solution to the problem of financial security of the domestic banking system.

\section{Research results}

The banking system, fulfilling the role of the circulatory system of the economy, closely interacts with various types of enterprises and industries, financial institutions in national and international financial markets. So, it is exposed to those negative factors that arise in the process 
of activity of the real sector of the economy, the financial system and the state as a whole.

The manifestations of negative trends in the economy of the state, conditioned by the political, military, legal and other factors, primarily affect the financial stability and financial security of the banking system. The latter, in turn, being in close interaction with all spheres of economic relations, accumulates structural imbalances, which in the long term intensify the effect of the cumulative effect of crisis phenomena. The deterioration of the financial security of the banking system, as a dynamic state in which the banking system is able to perform its functions, maintain a balance of key indicators of banking activity often leads to systemic economic crises. At the same time, it must resist external and internal threats without reducing the level of protection of the financial interests of stakeholders (owners, customers, employees, management and the state). After all, the consequences of a decrease in the level of capitalization and liquidity of the banking system are restrictions on lending to the real sector of the economy, currency and price instability. As a result, significant losses of owners and customers of banking institutions, caused by bank failures, devaluation and inflation risks.

A vivid example of this development is Ukraine, where during the economic crisis of 2014-2016 90 banks were bankrupt, and losses of customers, owners and the state are estimated at $38 \%$ of GDP [12]. It is worth noting that one of the reasons for such large-scale banking crisis in Ukraine was the absence of a comprehensive anti-crisis policy and systemic reforms of the national economy. Since the uncoordinated (the low level of coordination of monetary and fiscal policy, led to an increase in public debt and the cost of public borrowing) was traced, untimely and opaque (there is no official information on the criteria for withdrawing banks from the market and the criteria for their recognition as insolvent) making decisions on anti-crisis measures. A similar situation existed in the implementation of the policy of the so-called «purification» of the banking system, provision of refinancing loans, monetary and monetary policy as a whole led to enormous losses not only for banks, but for all economic entities (including individuals).

Thus, the financial security of the banking system directly depends on the effectiveness of the anti-crisis policy, requires the search for ways to optimize it in Ukraine taking into account the world experience in this area.

Thus, in the world practice of anti-crisis policy, one of the first and at the same time the most well-known state anti-crisis policies is the New Deal of the President of the United States of America, Franklin Delano Roosevelt. Despite criticism of the New Deal policy by some scientists, President F. Roosevelt and his administration managed to build a fairly good anti-crisis policy mechanism that helped overcome the Great Depression of 1929-1933 in USA and also becoming the basis for the formation of the «Keynesian revolution» in economic science, led to a departure from the dominant idea of self-regulation of the economy. In this context, the author of the paper [13] rightly notes: «If there is something really new in Keynes's theory, it is precisely the thoughtful criticism of this belief in the internal restorative forces of the market mechanism».

Actually, the mechanism of the anti-crisis policy of the Roosevelt administration was based on the following three elements of state power: President-Government-Congress. The effectiveness of Roosevelt's reforms depended on the unity of the three branches of US power, which complemented each other, which facilitated the adoption of many effective management decisions (Fig. 1).

Anti-crisis policy of the Roosevelt administration began to reform the banking system.

Thus, in the early days of Roosevelt's presidency, an «Extraordinary Law on Banks» was adopted, which declared «bank holidays» [14]. The law temporarily terminated all operations of banks that were part of the US Federal Reserve System (FRS). An important place in the anti-crisis policy of $\mathrm{F}$. Roosevelt was the information and communication policy with the population and business. For example, in a radio address on March 12, 1933, Roosevelt stated that: «bank holidays in many cases create great inconveniences, but at the same time they provide an opportunity to replenish the cash reserves, as required by the situation. Remember that not a single solvent bank has become any poorer by the dollar since its doors were closed last week. «[14] According to Friedman and Schwartz, more than 5,000 banks that worked at the time of holiday announcement did not open their doors after their graduation, and in 2000 they closed forever [15].

June 16, 1933 Roosevelt signed the Glass-Steagall Act, which introduced bank deposit insurance - mandatory for national banks and voluntary for state banks. To implement the reform, the Federal Deposit Insurance Corporation was created. According to the law, contributions up to 5,000 USD were subject to compulsory insurance. As early as the beginning of 1934, $80 \%$ of banks insured their deposits. The banking laws of 1933 proved to be so effective that they existed without changes and additions until 1956. The following figures show the strengthening of the reliability of banks: between 1921 and 1933 the depositors lost 45 cents for every 100 USD, and in the next thirty years they fell to 0.2 cent for the same amount [16].

In addition to reforming the banking system, a number of laws have been adopted that regulate all the most important spheres of the economy and contributed to the development of economic infrastructure. An important place in the anti-crisis policy of F. Roosevelt was fiscal and monetary measures, based on budgetary financing ( $\ll$ pump filling») of state projects. As well as concessional lending to commercial banks in order to ensure an adequate level of their financial stability and financial security. Practical implementation of fiscal stimulus is characterized by the following data: from 1932 to 1940, federal government spending increased from 4,266 to 1.061 billion USD. During the same period, industrial production grew by $60 \%$, which underlines the important role of fiscal stimulation of economic development [17].

In addition, it is worth noting a number of infrastructure and administrative organizations, in particular such as:

- Bank Deposit Insurance Corporation;

- administration of agricultural regulation;

- commodity-credit corporation;

- administration of national reconstruction and the like.

Such organizations contributed to the implementation of anti-crisis policies in specific sectors of the economy and together with the communicative policy formed public confidence in the authorities. 


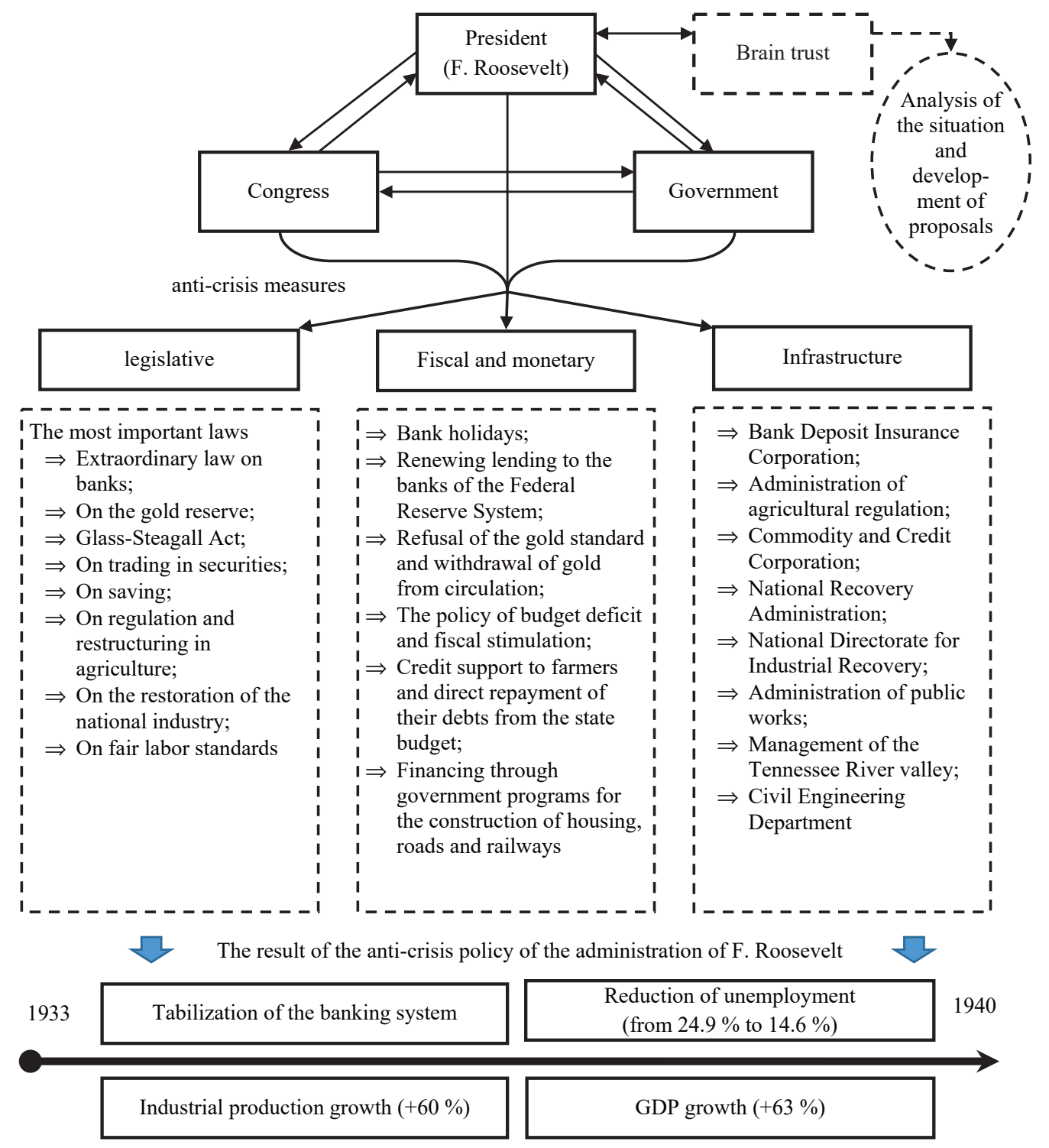

Fig. 1. The mechanism of the anti-crisis policy of the Roosevelt Administration in 1933-1940

Special attention, in the anti-crisis policy of the Roosevelt administration, deserves the fact that Roosevelt was and remains the only president uniting leading American scientists in the «Brain Trust», which goal was the development of ideology, strategy and public policy programs [15].

Thus, the anti-crisis policy of F. Roosevelt administration included the application of priority measures to improve the financial stability and financial security of banking institutions. These activities through the mechanism of concessional lending and targeted financing of state infrastructure projects were to become one of the engines for overcoming the Great Depression. Besides, the main role in the effectiveness of the anti-crisis policy was played by a clear co-ordination of the actions of all three branches of power (President-Congress-Government), which allowed:

- to promptly adopt the necessary anti-crisis laws;

- to create corresponding to the development of the Institute (Administration of National Rehabilitation, National Department for Industrial Recovery, Civil Construction Administration, etc.);

- to develop and implement a number of state programs for economic development.
Overcoming the problems in the risk-sensitive sector of the economy - the banking system, the development of infrastructure and institutions - has made it possible to form the basis for the financial stability and high rates of economic development of the United States of America at the beginning of the World War II.

The anti-crisis policy of $\mathrm{F}$. Roosevelt has become a kind of benchmark anti-crisis policy for future generations of the United States and other developed countries. So, if analyze the anti-crisis measures of such countries as the United States and the European Union in the context of overcoming the consequences of the global financial and economic crisis of 2008-2009, then the anti-crisis policy mechanism is much like the anti-crisis policy of the Roosevelt administration. However, it is worth noting that the only difference is the growing role of the country's banking and financial system in ensuring economic development. Therefore, the emphasis of anti-crisis measures is reduced to monetary regulation of the economy and ensuring a high level of financial security of the banking system, while fiscal measures are of an auxiliary nature. 
Let's analyze the vectors of the anti-crisis policy of the United States of America, the European Union and Great Britain during the global financial and economic crisis of 2008-2009. So, the main anti-crisis measures of the USA in 2008-2009 were aimed at ensuring financial stability and, first of all, were applied in the banking system by lowering the interest rate of the US Federal Reserve. However, at a time when the interest rate was approaching zero $(0.25 \%)$, the US Federal Reserve together with the Ministry of Finance decided to launch several targeted asset retirement (LSAP) programs, expanding the balance sheet assets through the increase of excess reserves in the financial system. The decision to take such measures meant a change in strategy, and the measures themselves subsequently became a program called Quantitative easing (QE).

As part of the quantitative easing, the US Federal Reserve adopted a number of special programs to support the banking sector, in particular:

- provision of loans to mutual funds on the loan of securities (AMLF);

- additional opportunities for lending on the loan of securities (CPFF);

- program for redemption of mortgage bonds or guaranteed by state mortgage agencies (MBSPP), etc.

In the context of the analysis of quantitative easing programs, it is possible to single out a program to buy back distressed assets from banks and other financial institutions (TARP). The implementation of TARP began in October 2008, the total limit of the program's funds was 700 billion dollars. To carry out the current monitoring of the US Congress, the post of the Special Program Inspector General (SIGTARP) was created for the expenditure of funds, which so far provides quarterly reports of the Congress.

It is important to note that the fiscal stimulation of the economy played a special role for the effectiveness of monetary policy and quantitative easing programs of the US Federal Reserve System. Its essence was to stimulate the mortgage market, the automotive market, and also support the American industry under the Law on Economic Recovery and Reinvestment (ARRA).

According to this law, 787 billion USD were allocated to support the US economy, which were to be spent for three years according to the following structure [4]:

- Tax incentives (288 billion USD).

- An increase in the unemployment benefit and other social payments ( 81 billion USD).

- Additional expenditure on health, education and science (120 billion USD).

- Investments in infrastructure and energy (298 billion USD).

The result of the TARP and ARRA programs is quite impressive, because their action led to GDP growth from $-4.2 \%$ in the first quarter of 2009 up to $5 \%$ in the 4 th quarter of 2009. Let's note that analysts do not analyze the quantitative impact of TARP programs on GDP dynamics, but focus their attention only on the ARRA fiscal stimulus program [4]. However, it is these programs to ensure financial stability and stimulate the economy are keys in the US anti-crisis policy in 2008-2010.

In addition, no less important place in the anti-crisis policy of the US took the reforms in the regulation of the financial sector. They were based on the introduc- tion of expanded state support for the largest financial corporations (capitalization and nationalization of Fannie Mae and Freddy MAS mortgage agencies, as well as AIG insurance company) and also the creation of new financial infrastructure institutions, such as the Council for the Supervision of Financial Stability and the Bureau for the Financial Protection of Consumers within the FRS, in fact provided the FRS with a mega-regulator function.

As for the anti-crisis policy of the European Union, by analogy, the United States was primarily aimed at ensuring a high level of financial stability and financial security of the banking systems of the EU member states.

Thus, under conditions of tight dependence of commercial banks on lending to the central bank, the Board of Governors of the European Central Bank (ECB) decided to provide the banking sector with unlimited liquidity. To this end, since October 15, 2008 the ECB has moved to the distribution of funds at auctions at a fixed rate and the satisfaction of all applications. Such actions of the $\mathrm{ECB}$, together with a reduction in the key interest rate to almost zero, meant a transition to a quantitative easing policy that was implemented through the main financial institutions of the European Union and had significant fiscal support. Among the main measures of anti-crisis policy in 2008-2010. In the European Union, it is possible to distinguish the following:

- provision by the European Investment Bank (EIB), which became the main counterpart of the ECB, of additional loans to small and medium-sized businesses in the amount of 30 billion EUR through commercial banks;

- accelerate the financing of the EIB projects aimed at combating global climate change, energy security, infrastructure development, in particular in the transboundary dimension. This was facilitated by an early increase in the authorized capital of the bank in 2010 at 60 billion EUR;

- strengthening the role of the European Bank for Reconstruction and Development (EBRD) in reforming the financial sector and private entrepreneurship in the new EU Member States by increasing the annual volume of project financing by 800 million EUR;

- strengthening the investment direction of projects within the framework of cohesion policy and restructuring their financing schemes by transferring payments from the EU budget to an earlier period. In particular, in the years 2009 and 2010, through EU structural funds, projects and activities for an amount of about 11 billion EUR were unscheduled financed in advance. In general, for the period 2007-2013, an implementation of such projects was planned to be 350 billion EUR [5].

A significant role in the anti-crisis policy of the EU was played in 2010. The European Stabilization Mechanism (hereinafter referred to as the «ESM») is a financial stabilization fund, which activities are aimed at achieving financial stability by providing financial assistance to countries that are experiencing financial difficulties. The Fund is formed by issuing financial instruments and debt securities for up to 30 years. The maximum amount of credit that can be provided to the State Party is 500 billion EUR [18].

In addition, budget discipline was strengthened. Within the framework of the Stability and Growth Pact, the 
European Commission adopted a number of measures, the main of which is the reduction of government spending and the volume of public debt. Each country is given a certain period due to its economic situation for improving macroeconomic indicators (for example, for Ireland until 2015, for Portugal - until 2014, for Italy - until the end of 2012) [5].

However, despite the large number of countries and the different levels of development of their economies, the anti-crisis measures of the European Union have a long-term impact. So, since 2014, the ECB has developed a number of new activities, including the launch of new programs for targeted long-term refinancing (TLTRO). ECB loans for up to four years and at lower rates than market loans, can be provided to banks in the euro area. If these loans meet the established criteria, then the final term of the programs is September 2018, the sum of the first two transactions conducted in 2014. Within the framework of the TLTRO, it amounted to 212,8 billion EUR (over 1200 banks of European countries took part in them). Another area of support for Eurozone banks is the program for the purchase of assets of private enterprises. One of them (ABSPP) aims to acquire high-quality ABS for the portfolio of the ECB, the other (CBPP3) continues a series of measures to purchase bonds with a cover.

The United Kingdom has a sufficiently effective experience of anti-crisis policy, where anti-crisis measures, as well as in the US and EU, were primarily directed to the banking sector. In particular, the Bank of England in April 2008 launched the Special Liquidity Scheme (SLS), according to which banks could temporarily exchange illiquid obligations from their portfolio to treasury bills. The Bank of England used the «quantitative easing» program launched in March 2009 as the main «non-standard» means of combating the crisis. And that consisted in the regular purchase of large quantities of securities (mainly treasury bonds). By January 2010, securities worth 200 billion GBP were purchased, which is equivalent to $14 \%$ of the UK's annual GDP. According to experts, the QE program contributed to the increase of government bonds and allowed to reduce losses of the financial and real sectors of the economy.

Important decisions were made with regard to the coordination of the UK's anti-crisis, monetary and fiscal policies, the basic aspects of which were spelled out in the Banking Act of 2009:

- Ministry of Finance is responsible for the structure of financial regulation and the relevant legislation and is accountable to the government in resolving the problems of the financial system and a specific list of measures;

- Bank of England provides additional liquidity in the banking sector. The main objective of the Bank is to contribute to risk assessment and help maintain the stability of the financial system;

- Financial Services Agency (FSA) regulates most of the markets for financial services, companies and exchange transactions.

In addition to monetary measures in the UK, considerable fiscal support for industry was applied, in particular, since October 13, 2008 the Ministry of Finance introduced the «Credit Guarantee Scheme». This scheme provided for the Ministry of Finance to provide funds totaling up to 250 billion GBP replace the obligations of banks with a deadline through a mechanism for the repurchase of securities issued by them with a maturity of up to three years. Also, the Ministry of Finance of England applied measures to reduce taxes on income of individuals and legal entities, and also launched a program to compensate tax payments from the state budget [4].

Analyzing the approaches to the anti-crisis policy of the developed countries of the world, one can draw a conclusion about the following scheme of interrelation between the anti-crisis, monetary and fiscal policies (Fig. 2)

The anti-crisis policies of the US, EU and the UK pursued three clear and interrelated goals:

- the first and most important goal is financial stability and a high level of financial security of the banking system;

- the second goal is economic growth;

- the third goal is to reduce the unemployment rate.

To ensure financial stability and a high level of financial security of the banking system, the anti-crisis policy was directed not only to the banking or financial sector. And understanding that the factors of financial stability and systemic risks are also born in the real sector of the economy, monetary and fiscal policies were effectively combined in the context of creating drivers for growth in both the financial and real sectors.

Considering the experience of the anti-crisis policy of the Roosevelt Administration in the period 1933-1940 and the central banks and governments of the United States of America, the European Union and Great Britain during the overcoming of the consequences of the financial and economic crisis of 2008-2009, let's consider the main vectors of overcoming the crisis phenomena in Ukraine. At the same time, let's focus on ensuring a high level of financial security of the domestic banking system.

\section{Legislative vector:}

1) legislative regulation of the functional component of the NBU's activities. Achieving this goal is extremely necessary to eliminate speculation and formulate clear criteria for the work of the National Bank of Ukraine in terms of monetary and exchange rate policy, because today there are significant differences in the interpretation of the functional activities of the NBU. So, according to Article 99 of the Constitution of Ukraine «ensuring the stability of a monetary unit is the main function of the central bank of the state - the National Bank of Ukraine». And according to Article 6 of the Law of Ukraine «On the National Bank of Ukraine» it is noted that the main function of the NBU is ensuring the stability of the monetary unit of Ukraine. However, it is added that in fulfilling its main function, the National Bank should proceed from the priority of achieving and maintaining price stability in the state. In practice, the achievement and maintenance of price stability in the state is carried out with the help of inflation targeting and causes sharp discussions on the implementation or non-implementation of the NBU Constitution of Ukraine. It should be noted that inflationary targeting has not been achieved for the last three years with the help of inflation targeting;

2) creating a legislative basis for the formation of a mechanism for managing the financial security of the banking system. First of all, this concerns legislative changes 
related to the licensing of banking activities, in particular the procedure for issuing licenses to banks with foreign capital, where significant participation belongs to the state or to government-related individuals. The presence of state banks of the Russian Federation, as an aggressor country, in the market of banking services is one of the main political (political blackmail) and economic (speculation in the currency market) threats. In addition, the Law of Ukraine «On Banking Activities» needs to amend the category banking apparatus and propose a definition of the financial security of the banking system, financial sustainability in order to determine the criteria for their deterioration and the threats that lead to such deterioration;

3) legislative regulation of the currency, stock and credit markets. In order to ensure a high level of financial security of the banking system of Ukraine, as well as to implement its development strategy, it is necessary to regulate the functioning of the three main markets where commercial banks operate:

- in the foreign exchange market, it is necessary to reduce currency restrictions and liberalize the movement of capital through the adoption of the Law on Foreign Exchange Operations;

- for the effective functioning of the stock market, it is necessary through amending the Law of Ukraine «On Securities and the Stock Market»:

- settle the issue of liability for transactions with related parties;
- raise standards for disclosure of information about investors and consumers;

- increase the level of protection of the rights of consumers and investors;

- credit market requires the streamlining of consumer, corporate and mortgage lending in terms of dollarization of loans, assessment of collateral, ensuring liquidity of collateral, protection of creditors' rights, requires adoption of the relevant law of Ukraine «On lending in Ukraine»;

4) legislative support of the banking infrastructure. Legislative support of the banking infrastructure as a set of interrelated elements and functions that have an auxiliary character and create the conditions for ensuring the functioning of the banking system. And also requires streamlining the activities of institutions such as credit bureaus, collection companies, asset management companies, a bank of «toxic» assets, and the like.

Today, the necessity of adopting the Laws of Ukraine «On the Activities of Collector Agencies in Ukraine», «On Private Performers», «On the Bank of» Toxic «Assets», «On the Organization of Formation and Circulation of Credit Histories», etc. is topical today.

2. Infrastructural vector. Infrastructural vector of anticrisis policy in the context of creating conditions for ensuring a high level of financial security of the banking system of Ukraine provides for the creation of new elements of the infrastructure not only of the banking system, but also of the state anti-crisis policy.

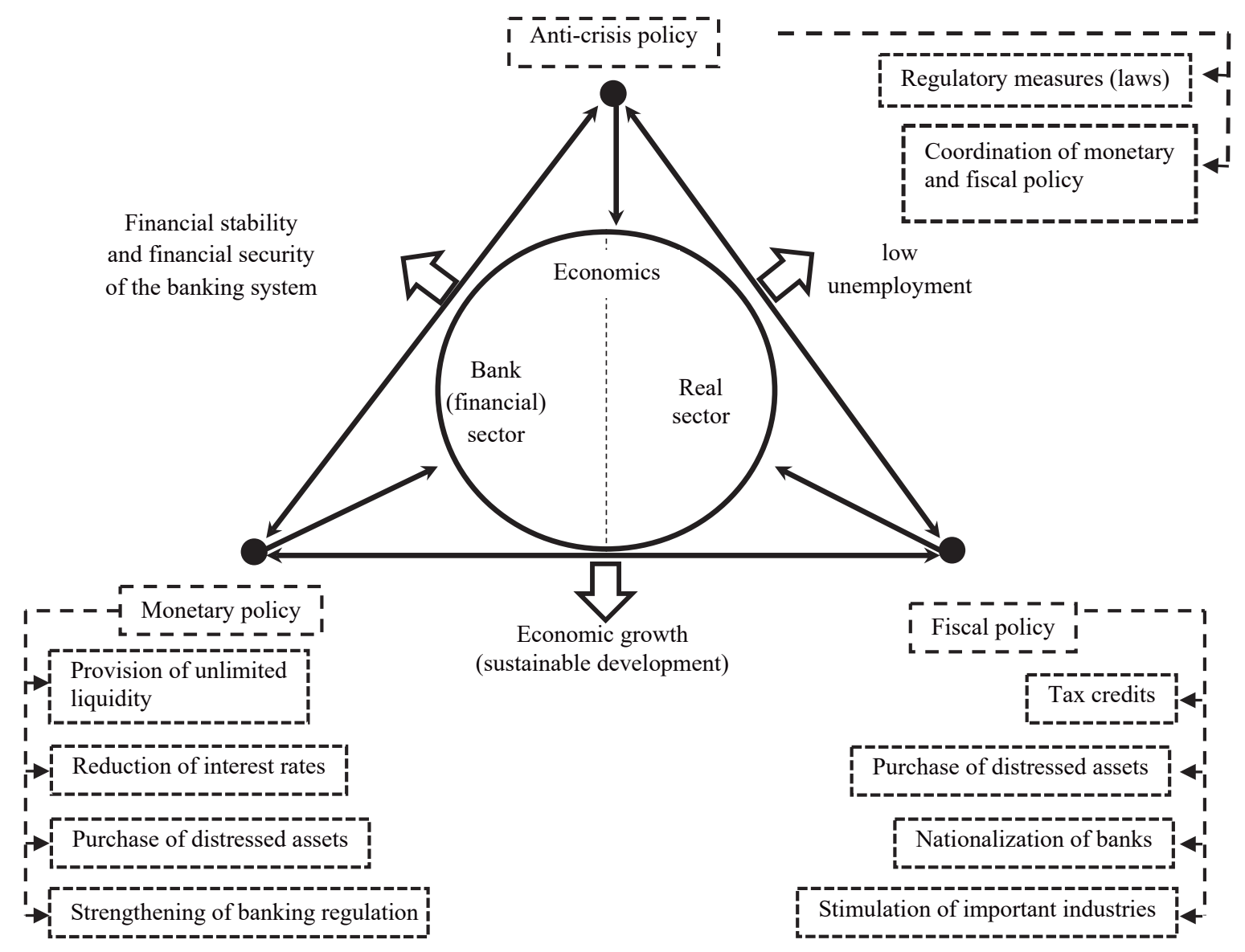

Fig. 2. Structural-logical scheme of interrelation of anti-crisis, monetary and fiscal policy in the context of ensuring economic security of the banking system, financial stability and economic growth 
Thus, at the state level, in order to ensure an effective anti-crisis policy in Ukraine, it is necessary to create a special anti-crisis center as a collegial decision-making body, which should include:

- President;

- Prime Minister and Minister of Finance;

- Chairman of the Board of the National Bank of Ukraine and Chairman of the Council of the National Bank of Ukraine;

- Chairman of the National Security and Defense Council.

The activity of the anti-crisis center should be based on an analysis of the economic, social and military-political situation in the country and abroad. On this basis, proposals and legislative initiatives should be developed for the legislature to adopt bills that optimize monetary and fiscal policies or other spheres of the economy.

A special role in the activity of the anti-recessionary center should be allocated to the brain trust (like F. Roosevelt's brain trust), which main tasks should be:

- analysis and research of the economy, social sphere, politics and international situations;

- development of forecast scenarios and analytical reports for the anti-crisis center.

Based on the processing of analytical reports and recommendations of the brain trust, the anti-crisis center should develop proposals for improving monetary and fiscal policies in terms of anti-crisis policies.

On the infrastructure of the banking system, it is necessary to create or optimize the activities of the following institutions:

1) NBU credit registry. The creation of a credit register of the National Bank of Ukraine will improve the monitoring of the concentration of credit risk, including strengthening the monitoring of large business groups, in particular those related to the owners of banks. And also to reduce the share of problem loans that will have a positive impact on the financial security of the banking system of Ukraine;

2) Optimization of the activity of the Bureau of Credit Histories. One of the main problems of the functioning of the credit history bureau in Ukraine is the lack of opportunities to obtain a sufficient amount of information about the customers of banks due to the lack of access to state control bodies, in particular:

- state fiscal service;

- tax police;

- Ministry of Internal Affairs.

It does not provide an opportunity to form an integral credit history of bank customers, and therefore to identify threats to the financial security of the banking system on the part of the credit market. In this case, it is necessary to organize the Unified State System of Credit History Bureaus with full access to the databases of the State Fiscal Service, the Tax Police, and the Ministry of Internal Affairs. This will allow to select a sufficient amount of information about bank customers and generate credit histories that will be sufficient to adequately assess the creditworthiness of borrowers;

3) creation of the Department of supervision of violation by banks of legislation in the sphere of money laundering. The National Bank of Ukraine, based on the analysis of its press releases, is effectively monitoring the violation by banks of legislation in the field of money laundering. However, for more concentrated supervision, it is advis- able to create a separate Department for the supervision of violations by banks of legislation in the field of money laundering;

4) creation of a bank of «toxic» assets;

5) reformatting the activities of state-owned banks. Almost during the whole period of functioning of state banks, a discourse is being held about the expediency and effectiveness of their functioning. The main directions of reformatting the activities of state-owned banks should be the following:

- provision of investment functions to state banks (such as the European Investment Bank), which will allow the National Bank of Ukraine to influence the development of the economy by providing soft loans for refinancing and ensuring their targeted use to finance government development programs;

- expansion of operations of state banks in the interbank credit market in order to maintain its volume during the crisis period, which in turn will support the liquidity of the banking system at the proper level;

- creation of a specialized state development bank on the basis of UkrGasBank, which should operate with the means of refinancing the NBU and the Government's funds to finance the development of small and mediumsized businesses, as well as state infrastructure projects.

3. Monetary vector:

1) creation of institutional, legal, economic conditions for effective functioning of inflation targeting, which requires the fulfillment of the following conditions:

- institutional independence of the central (national) bank;

- high level of qualification of analysts and a reliable statistical base, since to use the inflation targeting mode it is necessary to be able to reliably predict it; - perfect structure of the economy in a country that uses the inflation targeting policy: prices should be free, the economy should be free from fluctuations in prices for the export of raw materials and the exchange rate, as well as the minimum level of dollarization;

- developed financial system. To ensure its stability it is necessary to have a stable banking system and a developed financial market.

As it is possible to see, for today, none of the conditions necessary for effective functioning of inflation targeting have been met, which carries significant threats to the stability and financial security of the banking system.

Therefore, it should be noted that the National Bank of Ukraine without the appropriate support of the Government is not able to achieve these conditions, calls for the formation of a new concept of coherence between the government and the NBU. Especially it concerns the reduction of the monopolistic and administrative component of pricing for consumer goods, fuel, electricity and other goods, which weights are the largest in calculating the level of inflation. In addition, it is necessary to ensure an effective and reliable collection of statistical data on the regions of the country, including the spontaneous markets, prices on which have a significant impact on Ukrainian welfare;

2) ensuring a floating exchange rate and the growth of official reserve assets. Providing a floating exchange rate and the growth of official reserve assets requires a radical change in not just one monetary policy, but conditions and factors of influence on the exchange rate. The main 
among them is the structure of national exports, which has a commodity orientation and, as a result, is extremely vulnerable to fluctuations in commodity prices in world commodity markets. The change in the structure of exports requires several years of effort, subject to effective reforms that can't be implemented without the support of the Government. Therefore, in this aspect, government support is very important. The role of the National Bank of Ukraine in the context of creating the conditions for ensuring a floating exchange rate is reduced to the introduction of effective currency control at all stages of the currency and currency values movement. And also the formation of a balanced policy of foreign exchange interventions, which should be based on the principles of timeliness, rationality, national interests;

3) increasing the effectiveness of interest rate policy and the refinancing mechanism. The need to improve the effectiveness of interest rate policy lies in the fact that in a floating exchange rate, interest policy is the most important area of activity of the National Bank of Ukraine. After all, by changing key interest rates, there is a correction of the liquidity of the banking system and the money supply, the dynamics of which affect inflation and the exchange rate. The main task of the National Bank in the implementation of inflation targeting is balancing interest rates on active and passive operations in order to avoid excessive cost of refinancing loans and excessive benefits from investing banks in deposit certificates. This can lead to the accumulation of excess liquidity surplus and a significant reduction in lending to the real sector. This scenario was implemented in Ukraine during 2014-2017. Therefore, in order to increase the effectiveness of interest rate policy and the refinancing mechanism, it is necessary:

- improve the methodology for the development and implementation of interest rate policy in conditions of the floating exchange rate regime of the national currency;

- interest policy should be aimed at optimal management of the liquidity of the banking system and the restoration of the full operation of the interbank market;

- consider the possibility of optimizing the boundaries of the interest rate corridor and its expansion by reducing rates on NBU deposit certificates;

- revise the definition of the key rate and move away from practice when the key rate (key policy rate) is the rate for the passive operations of the National Bank (for two-week NBU deposit certificates);

- in conditions of critical compression of crediting in the real sector as a key rate, it is expedient to choose the target rate of the interbank market or the rate for certain active operations of the NBU;

- consider the introduction of instruments and operations of monetary policy to stimulate bank lending to the real sector of the economy;

- to this end, it is advisable to develop medium-term instruments and models for refinancing transparent and stable Ukrainian banks to increase their portfolios of loans granted to enterprises in the real sector, in particular high-technology, and small and medium-sized businesses (funding for lending scheme). Develop clear performance indicators and mechanisms for monitoring the implementation of these schemes [19];
- consider the possibility of a full and prompt execution by the National Bank of the function of a bank of banks as a lender of last resort with a view to ensuring the stability of the banking system;

4) improving the operations of the National Bank of Ukraine on domestic government bonds (DDB). The mechanism of operations of the National Bank of Ukraine with domestic government loan bonds requires improvement not in the introduction of new instruments or types of government securities, but in optimizing the volumes of DDB use. After all, through the purchase of government bonds in the primary market, the central bank actually finances the state budget, significantly limits its independence and the ability to promptly influence the parameters of the money supply. Therefore, one of the possible measures to reduce the volume of operations of the National Bank of Ukraine is establishing a «ceiling» of DDB volumes in the NBU balance sheet. This, on the one hand, encourages the Government to search for alternative sources of financing the state budget, and on the other hand it will allow the NBU to more effectively manage the money supply and liquidity of the banking system. This, in turn, will become one of the conditions for ensuring low inflation rates in the country.

4. Fiscal vector. In the context of inflation targeting, fiscal policy must have concerted monetary objectives and measures, in particular to reduce non-monetary inflation, and to ensure the financial security of the banking system by timely capitalizing or recapitalizing the system of innovative banking institutions. Thus, the main measures in the sphere of fiscal policy should be the following:

- demonopolization of the economy;

- restriction of the practice of administrative price regulation;

- refusal to tax bank deposits, which will increase their volumes;

- creating conditions for the formation of a positive business climate, and the like.

\section{SWOT analysis of research results}

Strengths. Strengths of research include:

1. The presence of banks with foreign capital of European banking groups that:

- increase the level of financial stability of the banking system;

- increase the level of competition;

- promote the implementation and adaptation of international practice of banking business in domestic practice.

2. The presence of four large banks with state participation (with the proper organization of their work can be the pillars of financial stability of the banking system and lending to the economy).

3. Increase the transparency of banking activities due to the disclosure of information about owners and controllers of banking institutions (reduces the level of abuse in the banking system, in particular, reduces the volume of related lending).

4. Implementation of the Cashless economy project, aimed at promoting non-cash payments in Ukraine (an increase in the share of non-cash payments increases the volume of bank resources). 
Weaknesses. The weaknesses of the study include:

1. Low level of financial security, financial stability, capitalization and liquidity.

2. High level of concentration of bank assets in 5 largest banks, 3 of them with state capital (due to ineffective policy of the NBU in the development of banking infrastructure and unsystematicity during overcoming of crisis phenomena and withdrawal of banks from the market).

3. A high proportion of capital and asset concentration of banks with Russian capital (due to ineffectiveness of legislation and banking supervision)

4. The inability of commercial banks, independently of the state, to accumulate the necessary amount of resources to finance large-scale investment projects (due to high economic and political risks, as well as low confidence in banks).

5. High level of dollarization of assets and liabilities of banking institutions (due to inefficient legislation and banking supervision).

6. High level of overdue loans, which leads to significant losses (due to devaluation, inflation, a decrease in the creditworthiness of borrowers).

7. Extremely low efficiency of banking supervision (due to ineffectiveness of the banking legislation and low transparency of the NBU).

8. Low level of legislative support for banking activities (regarding the definition of goals and functions of the NBU, licensing of banking activities, regulation of banks with foreign capital).

Opportunities. Opportunities for development include:

1. Increase the effectiveness of monetary and monetary policy (will help reduce the cost of banking resources, interest rates, stabilization of the exchange rate, etc.).

2. Increase the efficiency of banking supervision (help reduce the risks of banking activities and increase the effectiveness of banking management).

3. Optimization of banking legislation (is a pledge to improve the effectiveness of banking supervision and banking management).

4. Introduction of the Basel III principles (increase the effectiveness of bank risk management and the overall level of financial security of the banking system).

5. Strengthening the system of banking management and risk management (will increase the level of financial security of the banking system of Ukraine).

6. Increased competition (to promote the diversification of banking services to reduce their cost to customers).

7. Creation of a bank of «toxic» assets (it will allow to «free» the balance sheets of banks from problem loans, thereby increasing their level of profitability and financial security).

8. Decrease in the share of Russian capital in the banking system of Ukraine (increase the level of financial security of the banking system and Ukraine as a whole).

Threats. The research threats include:

1. The low level of independence of the National Bank of Ukraine on the domestic and foreign arenas (adversely affects the effectiveness of monetary policy and banking supervision).

2. Lack of flexibility in monetary policy (leads to belated reaction to threats).

3. Low level of coherence of monetary and fiscal policy (hinders the adoption of effective solutions to overcome imbalances in the development of the banking system).
4. High level of dependence on external shocks (leads to frequent changes in the financial security situation in the banking system of Ukraine).

5. Absence of confidence of depositors in the banking system of Ukraine (leads to the formation of a short-term resource base of domestic banks).

6. High concentration of political and economic risks (generates negative business expectations and is one of the reasons for the outflow of depositors from the bank).

7. Low level of business activity (reduces the ability of banks to attract funds from corporate clients).

8. High level of shadow economy (reduces the ability of banks to raise additional funds for current and deposit accounts).

\section{Conclusions}

1. In analyzing the experience of the formation of the anti-crisis policy mechanism of the President of the United States of America, Franklin Delano Roosevelt, as an effective example in this research, the following conclusion is drawn. First of all, the effectiveness of anti-crisis policies depends on the level of coordination of the main branches of government: president - legislative body - government. Only thanks to the coordination of efforts, timeliness and transparency of decision-making by all branches of power developed countries of the world managed to overcome the most massive in the history of mankind's crisis and their consequences: the Great Depression of 1929-1933 and the global financial and economic crisis of 2008-2009. Secondly, in addition to ensuring a high level of financial security of the banking systems of foreign countries, it was possible to achieve economic growth as a whole. Such results of the anti-crisis policy are due to its complexity and consistency in the application of anti-crisis measures, which provided for:

- adoption of new laws (for example, Dodd-Frank);

- creation of new institutions of financial infrastructure

(the brain trust, the National Reconstruction Administration);

- introduction of non-traditional measures of monetary policy (quantitative easing);

- facilitating the conditions for doing business together with parallel observance of fiscal discipline.

2. Analyzing the vectors of the anti-crisis policy of the United States of America, the European Union and Great Britain during the global financial and economic crisis of 2008-2009, such conclusion is drawn. The anti-crisis policy of the developed countries of the world, first of all, is aimed at solving the problems of the most important and at the same time the most vulnerable sector of the economy - the banking system, the main task being:

- preservation of banking institutions in the market and cleaning their balances from «toxic» assets;

- creation of a long-term resource base by providing long-term refinancing loans;

- formation of the basis for renewing lending to the real sector of the economy by both reducing the cost of resources (reducing key interest rates), and expanding the provision of liquidity and the like.

As a result, the banks' profitability level was improved, the volume of problem assets was reduced, the crediting of the real sector was expanded, and the confidence in the banks was restored by the market players. This ulti- 
mately led to an increase in the level of financial security of banking systems.

3. Analyzing the anti-crisis actions in Ukraine in 20082009, it is found out that the Ukrainian anti-crisis policy contained radically opposite measures:

- non-transparent withdrawal of banks from the market;

- increase of interest rates;

- creation of conditions for stopping crediting of the real sector;

- absence of legislative changes;

- increase in the monopolization of the economy and the like.

Such anti-crisis policies led to deterioration in the financial security of the banking system and huge losses for the economy as a whole.

4. Denoting the vectors of overcoming the crisis phenomena in Ukraine, the experience of the analyzed foreign countries was implemented in order to ensure a high level of financial security of the domestic banking system, a number of actions were proposed. First of all, the effectiveness of the anti-crisis policy in Ukraine, as well as the management of the financial security of the banking system will depend on its complexity, co-ordination of the actions of the President, the Verkhovna Rada, the Cabinet of Ministers and the National Bank of Ukraine. The implementation of anti-crisis policies in four areas of legislative, infrastructure, monetary and fiscal will:

- streamline banking legislation (in the sphere of licensing, lending, system-friendly banks, etc.);

- create new elements of the banking infrastructure

(a bank of «toxic» assets, development banks);

- optimize the monetary policy in the sphere of refinancing, management of interest rates and exchange rates; - create a positive business climate.

All these measures will allow increasing the level of financial security of the banking system of Ukraine and will allow banks to effectively perform their functions in the process of forming the economy of sustainable development.

\section{References}

1. Keynes J. M. The General Theory of Employment, Interest, and Money. New Delhi: Atlantic Publishers, 2008. 357 p.

2. Friedman M. The Role of Monetary Policy // The American Economic Review. 1968. Vol. 58, No. 1. P. 1-17.
3. North D. C. Institutions, institutional change and economic performance. Cambridge university press, 1990. 153 p. doi: http:/ doi.org/10.1017/cbo9780511808678

4. Opyt drugikh stran: est' chemu pouchit'sya. Chast' 1 / Aleksashenko S. V. et al. // Ekonomicheskaya politika. 2011. No. 1. P. 23-54

5. Boiar A. O. Antykryzova polityka Yevropeiskoho Soiuzu u period 2008-2010 rr.: vysnovky dlia Ukrainy // Zbirnyk naukovykh prats Natsionalnoho universytetu derzhavnoi podatkovoi sluzhby Ukrainy. 2011. No. 1. P. 77-92

6. Podkolzina I. A. Antikrizisnaya politika monetarnykh vlastey zony evro // Den'gi i kredit. 2010. No. 10. P. 51-60.

7. Vavra D. Inflation Targeting Experience: Lessons for Ukraine // Visnyk of the National Bank of Ukraine. 2015. Vol. 2015, No. 233. P. 39-53. doi: http://doi.org/10.26531/vnbu2015.233.039

8. Coibion O., Gorodnichenko Y. Inflation Expectations in Ukraine: A Long Path to Anchoring? // Visnyk of the National Bank of Ukraine. 2015. Vol. 2015, No. 233. P. 6-23. doi: http:// doi.org/10.26531/vnbu2015.233.006

9. Bukovynskyi S. A., Unkovska T. Ye., Dzhus M. O. Do pytannia rozrobky Stratehii monetarnoi polityky Natsionalnoho banku Ukrainy // Ekonomika Ukrainy. 2015. No. 8. P. 4-30.

10. Mishchenko S. V., Mishchenko V. I. Poiednannia funktsii stratehichnoho rozvytku ta antykryzovoho upravlinnia $\mathrm{v}$ diialnosti tsentralnykh bankiv // Aktualni problemy ekonomiky. 2016. No. 2. P. 266-272.

11. Dziubliuk O. Aktualni problemy rozvytku bankivskoi systemy // Bankivska sprava. 2016. No. 1. P. 3-32.

12. Zvit pro finansovu stabilnist // Natsionalnyi bank Ukrainy. URL: https://bank.gov.ua/doccatalog/document?id=50604904

13. Blaug M. Ekonomicheskaya mysl' v retrospektive. Moscow: Delo Ltd, 1994. 688 p.

14. Ruzvelt F. D. Besedy u kamina. O krizise, oligarkhakh i voyne. Moscow: Algoritm, 2012. 350 p.

15. Gus'kov D. N. Politika «Novogo kursa» Franklina Delano Ruzvel'ta v nachale Velikoy depressii. Tambov: Gramota, 2015. No. 3 (53), Part 3. P. 43-46.

16. Sogrin V. V. Istoricheskiy opyt SSHA. Moscow: Nauka, 2010 $581 \mathrm{p}$.

17. Sogrin V. V. Novyy kurs: F. D. Ruzvelta: edinstvo slova i dela // Obshhestvennye nauki i sovremennost'. 1991. No. 3. P. 146-156

18. European Financial Stabilisation Mechanism (EFSM). URL: http:// ec.europa.eu/economy_finance/eu_borrower/efsm/index_en.htm

19. Analiz efektyvnosti monetarnoi polityky Natsionalnoho banku Ukrainy. URL: https://feao.org.ua/wp-content/uploads/z2016/ 08/FEAO_Analysis-of-the-NBU-Monetary-Pollicy-Effectiveness A5_03.pdf

Vasylchyshyn Oleksandra, PhD, Associate Professor, Department of Taxation and Fiscal Policy, Ternopil National Economic University, Ukraine, e-mail: volexandra@gmail.com, ORCID: https://orcid.org/ 0000-0002-9948-5532 